九州大学学術情報リポジトリ

Kyushu University Institutional Repository

\title{
Serological studies on $F \_1$ hybrid of Cucumis sativus L.
}

Fukushima, Ei j i

Horticultural Laboratory, Department of Agriculture, Kyushu University

Matsui, Tsuyoshi

Biotron Institute, Kyushu University

Eguchi, Hiromi

Kurume Branch, Horticultural Research Station

https://doi.org/10.5109/22765

出版情報 : 九州大学大学院農学研究院紀要. 14 (3)，pp.333-339，1968-03. Kyushu University バージョン：

権利関係 : 
Journal of the Faculty of Agriculture, Kyushu University, Vo1. 14, No. 3

March 30, 1968

Serological studies on $\mathrm{F}_{1}$ hybrid of Cucumis sativus L."

Eiji Funushima, Tsuyoshi Matsui ${ }^{2)}$ and Hiromi $\mathrm{E}_{\mathrm{GUCHI}}{ }^{3)}$

In modern biochemical science it is well known that changes of gene can be studied through differences in the protein structure. This criterion offers support that phylogenetic investigation could be carried out through the comparison of protein constituents between different genetic lines. Serological analysis is one of the powerful tools for comparative analysis of protein constituents, and has been utilized for hpylogenetic inquiries of cultivated plants. ${ }^{1,3,5,6)}$ One of techniques which may bring the information of pre dominantly phylogenetic importance is considered to be that of serological study on the $F_{1}$ hybrids. The $F_{1}$ hybrids of cultivated forms are very important for reasons of starting the first step of breeding by hybridization and of being the initiation of phylogenetic diffenentiation.

Present study has aimed at analyzing the relationship in protein constituents between the $F_{1}$ hybrid and its parents, and this paper deals with serological analyses of seed proteins of the $F_{1}$ hybrid and its parental varieties in cucumber.

\section{Materials and methods}

$\mathrm{F}_{1}$ hybrids of cucumber were raised by the cross between "Santō" and "Kurume-ochiai No. 1." The female parent, Cucumis sativus L. "Santō" is a horticultural variety belonging to the northern Chinese type, and the male parent, $C$. sativus "Kurume-ochiai No. 1" is one of the southern Chinese types. They have been maintained as the inbred lines through five generations. The species and varieties used were listed in Table 1.

Cucumber seeds were ground and pre-extracted with petroleum ether

1. A part of this study was presented at the Annual Meeting of Genetic Society of Japan in 1963.

2. Present address: Biotron Institute, Kyushu University.

3. Present address: Kurume Branch, Horticultural Research Station (Minist. of Agric. \& Forest.) Kurume, Fukuoka. 
to remove lipids. One hundred gm of the defatted seed meal was extracted with $500 \mathrm{ml}$ of $\mathrm{M} / 30$ phosphate buffer of $\mathrm{pH}$ 8.5. The extract was lyophilyzed for antigens. Two $\mathrm{ml}$ of 1 per cent protein solution was emulsified with an equal volume of Freund's adjuvant, and injected intramusculary to rabbits weighing about $2 \mathrm{~kg}$. The second injection was followed at interval of 2 weeks by the same method as the first. Rabbits were exanguinated 4 wecks after the second injection. Serum was separated from blood and preserved with sodium azide (0.1 per cent). The modified Ouchterlony's method ${ }^{7}$ was employed for the double diffusion test. Agar-gel plates for immuno-diffusion were prepared in petri dishes and were made $2 \mathrm{~mm}$ in thickness. The gel medium contained $1.3 \mathrm{gm}$ of agar, $0.9 \mathrm{gm}$ of sodium chloride and $0.1 \mathrm{gm}$ of sodium azide in $100 \mathrm{ml}$ of distilled water. Basins were cut into the agar-gel plate according to the Matsui's diagram ${ }^{6}$ of basin arrangement. Threc lower basins were respectively filled with $0.2 \mathrm{ml}$ of antiserum and three upper ones were filled simultaneously with $0.2 \mathrm{ml}$ of each protein extract ( 1 per cent solution of proteins). The agar-gel plates were incubated exclusively at $37^{\circ} \mathrm{C}$ for 2 weeks. Antigens and antibodies diffused into the agar-gel, and when they met, the corresponding antigen and antibody reactions resulted in the formation of individual precipitin lines.

Table 1. Cucumis and Cucurbita species used.

\begin{tabular}{cl}
\hline \multicolumn{1}{c}{ Species } & \multicolumn{1}{c}{ Horticultural varieties } \\
\hline Cucumis sativus L. & Santō \\
" & Kurume-ochiai No. 1 \\
$"$ & Natsu-fushinari \\
" & Jibae-ao \\
Cucumis melo L. & $\mathrm{F}_{1}$ hybrid (Santō $\times$ Kurume-ochiai No. 1) \\
Cucurbita mxima Duch. & Kurume-shirouri \\
\end{tabular}

Agar-gel plate used for immunoelectrophoresis contained $1.3 \mathrm{gm}$ of agar and $0.9 \mathrm{gm}$ of sodium chloride in $100 \mathrm{ml}$ of $\mathrm{M} / 30$ veronal buffer of $\mathrm{pH}$ 8.5. Parallel troughs for antiserum were cut into the agar-gel plate along electrophoretic track between the holes for samples as shown in figure 3. Each extract (1 per ccnt solution of the proteins) was respectively poured into individual holes in the agar-gel plate, and exposed for 15 hours to the stabilyzed voltage of $6 \mathrm{~V} / \mathrm{cm}$. Afer the electrophoretic separation, antiserum was poured into the troughs. The agar-gel plate was incubated at $37^{\circ} \mathrm{C}$ for a week. Precipitin arcs formed by the corresponding antigens and antibodies were examined. 


\section{Results}

Precipitin patterns obtained with anti- $F_{1}$ serum in the double diff usion test were ineffective in distinguishing the female parent, "Santō" and male parent "Kurume-ochiai No. 1" as shown in Fig. 1. On the other hand the $F_{1}$ hybrid appeared to be different in one of the precipitin lines from its parental varieties. This precipitin line was designated as $(\alpha)$ in Fig. 1, curving upward at both ends. That is, this precipitin line $(\alpha)$ appeared nearer to basin (S) and basin (O), and apart from ba$\sin (\mathrm{F})$ at the middle portion where this was superimposed on the other precipitin lines. In such a case as the same antigen-antibody system appeared at different location in a double diffusion plate, it has been known that this precipitin line shows "reaction of imperfect identity" ${ }^{6}$ ) in comparison of proteins. It is uncertain, however, that this precipitin line $(\alpha)$ will be corresponding to "reaction of imperfect identity" or to "reaction of non-identity," because this precipitin line disappeared at both ends. For the purpose of examinating this uncertain situation of the precipitin line $(\alpha)$ in some details, the anti- $\mathrm{F}_{1}$ serum absorbed with "Santō" antigen was prepared; $20 \mathrm{mg}$ of "Santō" proteins lyophilyzed was added to $1 \mathrm{ml}$ of anti- $\mathrm{F}_{1}$ serum and incubated at $37^{\circ} \mathrm{C}$ for 15 hours. It was centrifuged at $3,000 \times \mathrm{g}$, and supernatant was used in the double

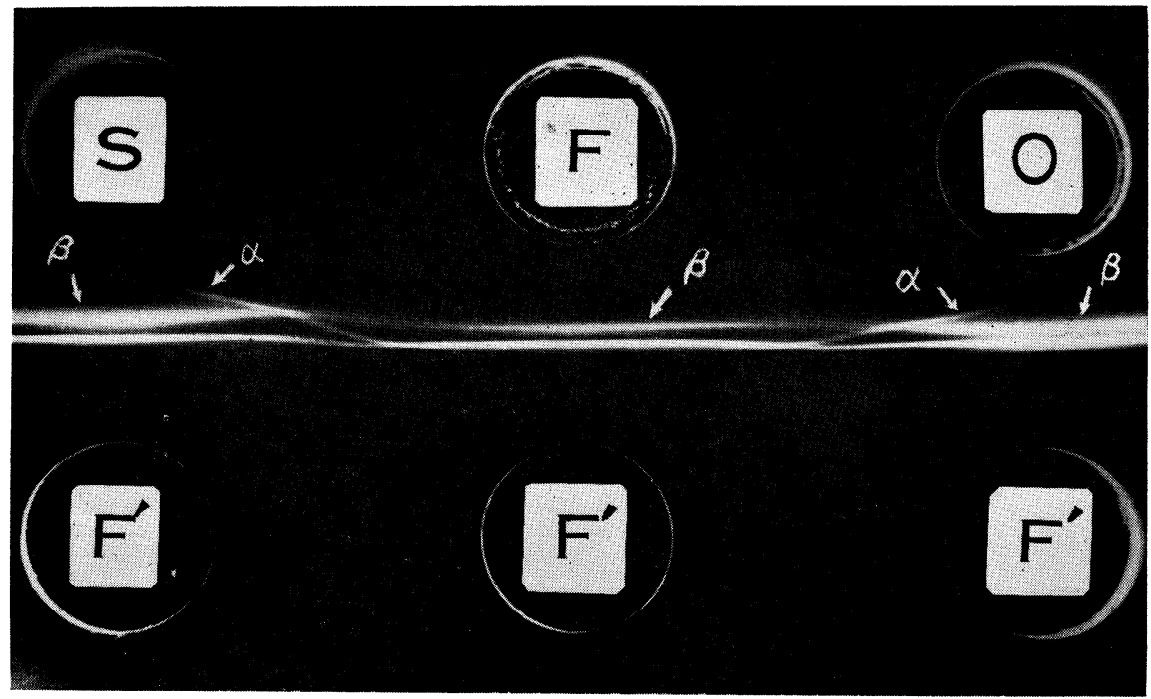

Fig. 1. Photograph of precipitin patterns obtained with anti-F ${ }_{1}$ serum in double diffusion test; (S), Cucumis sativus "Santō" antigen. (F), $\mathrm{F}_{1}$ hybrid ("Santō" "Kurume-ochiai No. 1.") antigen. (O), C. sativus (Kurume-ochiai No. 1) antigen. (F’), anti-F $F_{1}$ serum. 


\section{diff usion test.}

If the precipitin line $(\alpha)$ is corresponding to "reaction of non-identity," that is, the component forming precipitin line $(\alpha)$ is not contained in "Santō", this precipitin line $(\alpha)$ would be also detected in the double diffusion test using anti- $F_{1}$ serum absorbed with "Santō" antigen. As shown in Fig. 2, none of precipitin lines was detected in the test using the absorbed serum. This evidence suggests that the component forming the precipitin line $(\alpha)$ has been also contained in "Santō" and this repcipitin line would be corresponding to "reaction of imperfect identity". As mentioned above this precipitin line appeared more apart from the basin $(F)$ filled with $F_{1}$ hybrid antigen than from the basins (S) and $(\mathrm{O})$ with parentalanigens. Accordingly, the $\mathrm{F}_{1}$ hybrid seems to have possessed much larger amount of this component in comparison with the parental varieties.

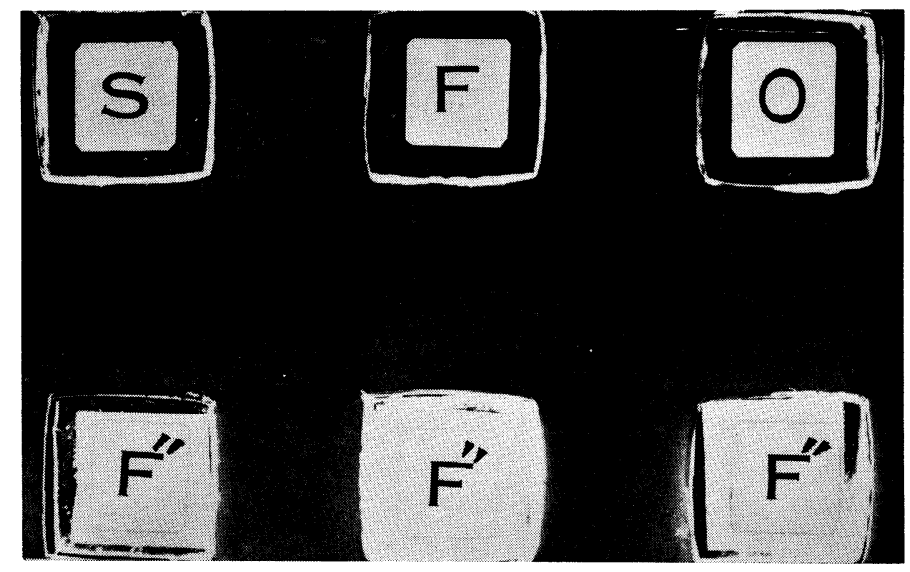

Fig. 2. Photograph of agar-gel plate in double diffusion test using absorbed serum; (S), "Santō" antigen. (F), $\mathrm{F}_{1}$ hybrid antigen. (O), "Kurume-ochiai No. 1" antigen. ( $F$ "), anti-F ${ }_{1}$ serum absorbed with "Santō" anti gen.

Furthermore, the difference between the $F_{1}$ hybrid and its parents was slightly found in the precipitin line $(\beta)$, which seems to be composed of several precipitin lines making a bandle. This precipitin line $(\beta)$ appeared to be thick in its width on both of right and left sides of an agar-gel plate, and to be thin in the middle portion as shown in Fig. 1. Such appearance of the precipitin line $(\boldsymbol{\beta})$ seems to be made by the fact that each one of these precipitin lines which compose precipitin ine $(\beta)$ was more or less dispersed at discrepant location in dividually on the both side portions of agar-gel plate, and was completely super- 
imposed together in the middle portion of the plate. The above fact suggests that each of these precipitin lines show the pattern of "reaction of imperfect identity" individually. And it has become appearant that the $F_{1}$ hybrid is somewhat different from its parental varieties in quantitative proportions of each of components forming these precipitin lines.

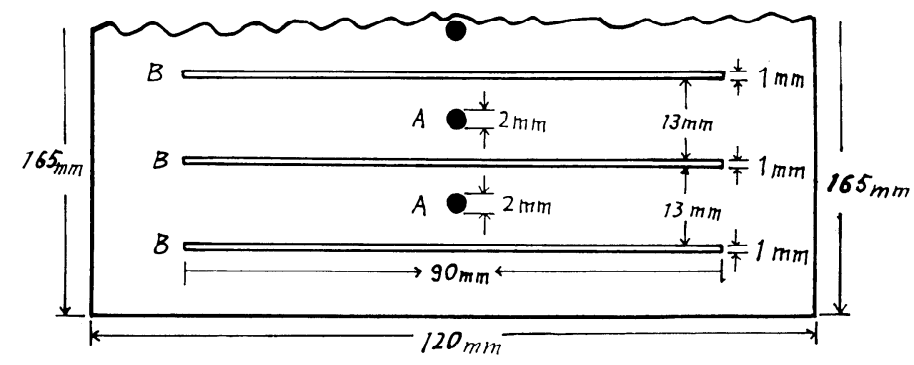

Fig. 3. Model of agar-gel plate for immunoelectrophoresis; The agar plate is $2 \mathrm{~mm}$ in thickness, and supported by glass plate $(165 \times 120 \mathrm{~mm})$. (A), hole for antigen. (B), trough for antiserum.

( J)

(D)

(M)

(S)

(F)

(O)

$(\mathrm{N})$

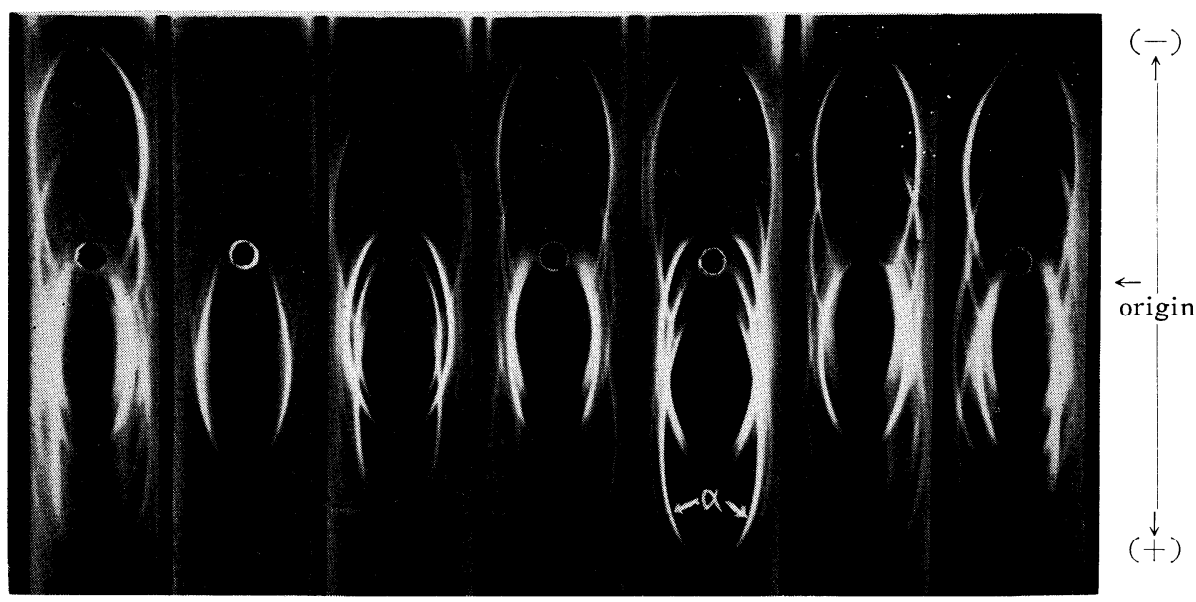

Fig. 4. Photograph of immunoelectrophoretic patterns obtainted with anti- $\mathrm{F}_{1}$ serum (in trough); (J), Cucumis sativus L. "Jibae-ao" antigen. (S), Cucumis sativus L. "Santō" antigen. (F), $\mathrm{F}_{1}$ hydrid ("Santō" $\times$ " Kurume-ochiai No. 1") antigen. (O), Cucumis sativus L. "Kurume-ochiai No. 1" antigen. (N), Cucumis sativus L. "Natsufushinari" antigen. (D), Cucurbita maxima Duch. "Delicious" antigen. (M), Cucumis melo L. "Kurume-shirouri” antigen. 
In immunoelectrophoresis the component which formed the precipitin line $(\alpha)$ migrated toward anode as shown in Fig. 4. Any appreciable differences among several cucumber varieties could scarcely be found in the precipitin arcs. On the other hand the cucumber varieties appeared to be difinitely different from Cucumis melo and still more different from Cucurbita maxima in the immunoelectrophoretic patterns. These inter-specific differences were much more significant than those between the $F_{1}$ hybrid and its parents of cucumber varieties. These findings suggest that the differences between the $F_{1}$ hybrid and its parents would be, in general, less in extent as compared with inter-specific differences, and to be on a level with intra-specific differences.

M. R. Irwin et al $^{4}$ reported that the species hybrid (Streptoptopelia chinensis $\times S$. risoria) possesses the "hybrid substance" which is detected serologically in the $F_{1}$ hybrid, but not in its parents. D. Schwartz ${ }^{9}$ has found in the maize "hybrid enzyme" which has esterase activity and is not conteined in its parents. E. Fukushima et al ${ }^{11}$ found that the $F_{1}$ hybrid (Brassica chinensis $\times$ B. napella) which was raised artificially, behaved serologically to be intermediate between the parental species. In the $\mathrm{F}_{1}$ hybrid of cucumber, hybrid protein was not found in the present experiment. The differences between the $F_{1}$ hybrid and its parental vareties of cucumber could be serologically observed in the quantitative proportions of each of the components in seed extracts, and were especially significant in the component forming the precipitin line $(\alpha)$. That is, the $\mathrm{F}_{1}$ hybrid appeared to possess a much larger amount of this component as compared with its parental varieties.

\section{Summary}

The relationships in protein constituents of seeds between the $F_{1}$ hybrid and its parental varieties of cucumber were analyzed by means of serological method.

The $F_{1}$ hybrid appeared to be different from its parental varieties in quantitative proportions of each component. The difference was especially significant in quantity of the component forming the precipitin line $(\alpha)$. That is, the $F_{1}$ hybrid has possessed a larger amount of this component than the parental varieties. In immunoelectrophoresis, this component migrated toward anode. There were scarcely any appreciable differences in precipitin arcs among several cucumber varieties. On the other hand these cucumber varieties appeared to be distinctly different from Cucumis melo and Cucurbita maxima in their immunoelectrophoretic patterns. These differences were more significant than those between the $F_{1}$ hybrid and its parental varieties of cucumber. These findings suggest that the differences between the $F_{1}$ hydrid and its par- 
ents would be less in extent as compared with the inter-specific differences, and on a level with intra-specific differences.

\section{Literature}

1) Fukushima, E., and Y. Maruyama, 1929, Proc. Imp. Acad. 5 : 473.

2) Graber, P., and C. A. Williams, 1953, Biochem. Biophys. Acta. $10: 193$.

3) Itoh, H., E. Fukushima, and T. Matsui, 1959, Japan. J. Breed. $9: 256$.

4) Irwin, M. R., and L. J. Cole, 1936, Exp. Zool. 73 : 85.

5) Kowarski, A., 1901, Deut. Med. Wschr. $27: 442$.

6) Matsui, T., 1964, Jour. Fac. Agric. Kyushu Univ. 13 : 179

7) Ouchterlony, O., 1949, Arkiv Kemi, Mineral Geol. B. 26 : 1.

8) Ouchetrlony, O., 1953, Acta Path. et Microbiol. Scand. 32 : 231.

9) Schwartz, D., 1960, Proc. Natl. Acad. Sci. U. S. $46: 1210$. 